\title{
Perancangan Sistem Pendaftaran Pasien Rawat Jalan Rumah Sakit Melalui Short Message Service Gateway (Studi Kasus: RS. Panti Wilasa "Dr. Cipto" Semarang)
}

\author{
${ }^{1}$ Tunggul Adi Bisono, ${ }^{2}$ Toni Wijanarko Adi Putra \\ ${ }^{1}$ Mahasiswa Program Studi Teknik Informatika STMIK ProVisi Semarang, toenk.bison@gmail.com \\ ${ }^{2}$ Dosen Program Studi Teknik Informatika STMIK ProVisi Semarang, t.wijanarko@gmail.com
}

\section{ARTICLE INFO}

Article history:

Received 23 July 2018

Received in revised form 30 July 2018

Accepted 3 Agustus 2018

Available online 17 Agustus 2018

\begin{abstract}
SMS Gateway technology used in the outpatient registration process is an applied technology in the field of information. Outpatient outpatient visits are an indication of the hospital's success in managing the public confidence of doctors and recontrol of the hospital. Use of SMS Gateway System aims to facilitate the delivery of information through SMS cheap, short and readable for each recipient. This study aims to provide an outpatient registration system at Rumah Panti Wilasa Hospital "Dr. Cipto "and doctor's schedule information via SMS Gateway. The design of this SMS gateway system using System Development Life Cycle (SDLC) method with 5 stages is System Planning, System Analysis, System Implementation and System Maintenance). This application design provides an SMS Gateway based registration information system that generates queue numbers for doctor checks, doctor's schedules and delivery of recontrol information for patients.
\end{abstract}

Keywords: SMS gateway, Registration, Doctor Re-Control, Patient Queue, Hospital

\section{PENDAHULUAN}

Kunjungan rawat jalan atau outpatient yang tinggi merupakan suatu indikasi keberhasilan rumah sakit dalam mengelola kepercayaan masyarakat yang melakukan periksa dan kontrol kembali ke rumah sakit tersebut.

Pasien yang masih memerlukan perawatan lanjutan di rumah sakit biasanya diminta untuk kontrol kembali terutama bagi pasien dengan penyakit kronis atau penyakit yang berlangsung sangat lama.

Rumah Sakit Panti Wilasa "Dr. Cipto" merupakan rumah sakit yang masih mengelola kunjungan pasien rawat jalan secara manual. Pasien yang melakukan registrasi harus mengantri cukup lama didepan loket pendaftaran. Bagi pasien yang sebelumnya sudah melakukan pendaftaran melalui telepon, petugas rumah sakit masih harus melengkapi entry data pasien yang kontrol atau periksa dokter saat datang ke rumah sakit disamping itu pasien juga masih kesulitan untuk mencari informasi tentang hari dan jam praktek dokter, RS. Panti Wilasa "Dr. Cipto" sebenarnya sudah menyediakan informasi Jadwal Dokter melalui brosur pelayanan rawat jalan tetapi hanya dapat diperoleh saat pasien datang ke rumah sakit atau per telepon dan melalui website RS. Panti Wilasa "Dr. Cipto" yaitu www.pantiwilasa.com.

Data kunjungan rawat jalan di RS. Panti Wilasa "Dr. Cipto" selama semester I dari Januari Juni tahun 2012 menunjukan adanya gap yang cukup besar yaitu sebesar 29\% pasien yang tidak melakukan kontrol kembali ke RS atau Lost Patient sekitar 14.856 orang seperti ditunjukan pada 
Gambar 1.1, angka kejadian pasien tidak kontrol kembali kemungkinan disebabkan oleh kendalakendala seperti :

1. Kendala Langsung

Petugas RS tidak mengingatkan pasien untuk kontrol ulang karena petugas tidak memiliki data pasien yang akurat.

2. Kendala Tidak Langsung

Pasien kesulitan melakukan pendaftaran per telepon karena RS hanya menyediakan 2 extensi.

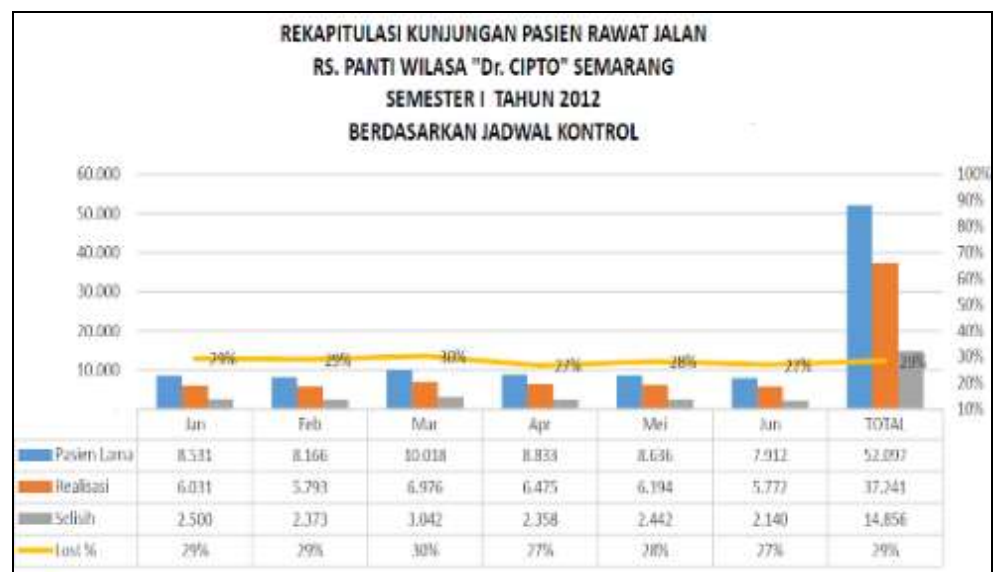

Sumber: Rekam Medis RS. Panti Wilasa "Dr. Cipto"

Gambar 1 Rekapitulasi Kunjungan Pasien Rawat Jalan Tahun 2012

Antrian pasien yang panjang dan tidak jelas waktu pelayanan dokter di rumah sakit menyebabkan pasien lebih memilih untuk datang langsung dan melakukan antrian langsung di RS.

Pasien tidak tahu kapan harus kontrol kembali ke dokter karena surat kontrolnya hilang atau petugas RS salah menulis jadwal kontrol. Pasien merasa sudah sembuh sehingga tidak perlu kontrol.

Handphone telah menjadi sebuah perangkat komputasi yang canggih selain berfungsi untuk melakukan dan menerima panggilan telepon, telepon seluler umumnya juga mempunyai fungsi pengiriman dan penerimaan pesan singkat (short message service / SMS). Fasilitas teks dipandang cukup efisien sehingga orang tidak harus menjawab saat itu juga tetapi pasti terbaca pesannya. Perangkat nirkabel ini dapat menerima informasi kapanpun dan dimanapun sepanjang terjangkau jaringan seluler penyedia layanan.

SMS gateway mulai dikenal dan diaplikasikan dalam berbagai bidang, seperti pendidikan, marketing dan kesehatan. SMS gateway di rumah sakit dapat diaplikasikan untuk menyampaikan informasi dan edukasi kesehatan di masyarakat, kemudahaan ini juga dapat digunakan untuk mendukung proses kegiatan rawat jalan di rumah sakit.

RS. Panti Wilasa "Dr. Cipto" pada saat ini membutuhkan media informasi yang lebih tepat, cepat, tidak membutuhkan waktu dan biaya yang besar, serta informasi yang mudah diakses dan disimpan. Media informasi berbasis SMS (Short Message Service) diharapkan dapat menjadi solusi dari permasalahan yang ada. Media SMS yang digunakan didistribusikan melalui sebuah aplikasi informasi yang berbasis SMS Gateway. 


\section{LANDASAN TEORI}

\subsection{Sistem dan Informasi}

Sistem adalah sekumpulan elemen yang saling terkait atau terpadu yang dimaksudkan untuk mencapai suatu tujuan [5]. Pengertian sistem informasi melalui pendekatan pada prosedur dan komponen [4]. Sistem adalah sekelompok komponen yang saling berhubungan dan bekerjasama untuk mencapai tujuan bersama dengan menerima input serta menghasilkan output dalam proses transformasi yang teratur [8].

Informasi merupakan kumpulan data yang diolah menjadi bentuk yang lebih berguna dan lebih berarti bagi yang menerima. Sumber dari informasi adalah data [4]. Kualitas informasi yang diharapkan tergantung empat hal pokok yaitu ; Akurat, Tepat Pada Waktunya, dan Relevan [4]. Sistem informasi didefinisikan sebagai suatu sistem dalam suatu organisasi yang mempertemukan kebutuhan pengolahan transaksi harian, mendukung operasi, bersifat manajerial dan kegiatan strategi dari suatu organisasi dan menyediakan pihak luar tertentu dengan laporan-laporan yang diperlukan [4].

Sistem informasi adalah kumpulan dari perangkat keras dan perangkat lunak serta perangkat manusia yang akan mengolah data menggunakan perangkat keras dan perangkat lunak tersebut [7]. Komponen-komponen sistem informasi secara rinci yaitu: Input, Output, Teknologi, Basis Data, dan Kendali [7]. Sistem informasi berbasis komputer mengandung arti bahwa komputer mempunyai peranan yang sangat penting dalam sebuah sistem informasi [8].

\subsection{Short Message Service (SMS)}

Short Message Service atau yang lebih dikenal dengan istilah SMS merupakan fitur yang digunakan untuk mengirim pesan dalam format teks [13]. Layanan SMS dapat digunakan oleh seluruh pengguna handphone, dengan adanya SMS dapat dipastikan bahwa tiap pesan yang masuk pasti terbaca oleh pemilik handphone [14]. Pengiriman pesan SMS oleh pengguna handphone melalui beberapa proses sebelum pesan tersebut akhirnya sampai tujuan [13]. Alur pengiriman SMS ditunjukkan dalam Gambar 2.

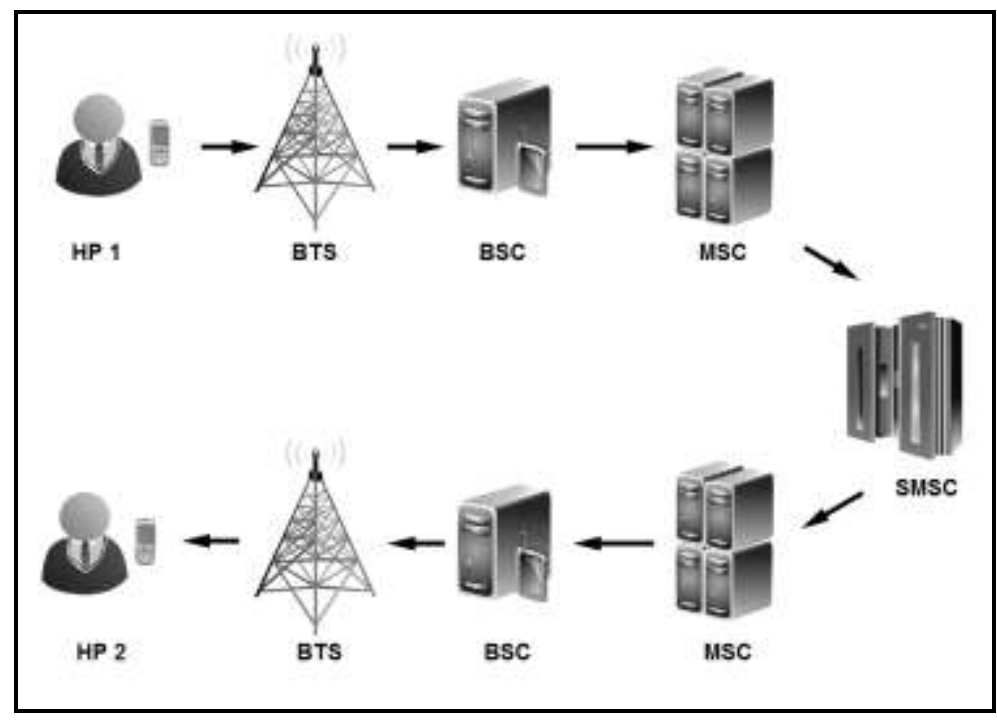

Gambar 2. Alur Pengiriman SMS [13]

Aplikasi SMS dibagi menjadi beberapa jenis kategori sesuai dengan kebutuhan pengguna [13]. Beberapa jenis aplikasi SMS diantaranya: SMS Premium, SMS Blasting, SMS Pull, SMS Plush, SMS Gateway. 


\subsection{Database}

Database adalah kumpulan informasi yang disusun berdasarkan cara tertentu dan merupakan suatu kesatuan yang utuh [2]. Suatu perangkat lunak yang ditujukan untuk menangani penciptaan, pemeliharaan, dan pengendalian akses data. Relational Database Management Systems adalah sebuah aplikasi yang dirancang untuk mengatur sebuah database sebagai sekumpulan data yang disimpan secara terstruktur [5]. Unified Modelling Language merupakan bahasa pemodelan standar pada rekayasa perangkat lunak, dengan menggunakan Unified Modelling Language akan berdampak kepada peningkatan produktifitas dan kualitas serta pengurangan biaya dan waktu [9].

2.4. Rumah Sakit

Rumah Sakit didefinisikan sebagai institusi pelayanan kesehatan yang menyelenggarakan pelayanan kesehatan perorangan secara paripurna dan menyediakan pelayanan rawat inap, rawat jalan, dan gawat darurat [16].

Rekam medis adalah berkas yang berisi catatan dan dokumen antara lain identitas pasien, hasil pemeriksaan, pengobatan yang telah diberikan, serta tindakan dan pelayanan lain yang telah diberikan kepada pasien [10].

Penerimaan pasien adalah kegiatan pada Tempat Pendaftaran Pasien Rawat Jalan (TPPRJ) yang mempunyai fungsi untuk melayani pendaftaran pasien Rawat Jalan yang belum atau sudah pernah berobat di RS. Panti Wilasa "Dr. Cipto" yang meliputi: Kunjungan Baru, Kunjungan Lama, Pasien Rawat Jalan, Pasien Umum, Pasien Kerjasama dan Pasien Pribadi [11].

\subsection{Tempat Pendaftaran Pasien Rawat Jalan (TPPRJ)}

Prosedur Penerimaan Pasien Rawat Jalan Tugas-tugas TPPRJ meliputi: Menerima pendaftaran pasien, Melakukan pencatatan pendaftaran (Registrasi), Menyediakan formulir, Mengarahkan pasien ke Unit Rawat Jalan (URJ) atau Poliklinik yang sesuai dengan keluhannya [11].

\subsection{Penelitian terdahulu}

Dalam temuan penelitian terdahulu beberapa penulis menerapkan SMS Gateway sebagai alat solusi bagi permasalahan yang ada bagi masing-masing obyek diantaranya: Menggunakan Aplikasi SMS Gateway, dengan proses Pasien mendaftar melalui SMS dengan format yang sudah ditentukan [3]. Sedangkan output yang dihasilkan berupa SMS untuk pasien tentang nomor antrian periksa di puskesmas. Perangkat yang digunakan Modem GSM dengan jenis SMS Autoreplay.

Penelitian sejenis yaitu Aplikasi menggunakan SMS Gateway dengan proses Pasien mendaftar melalui SMS dengan format yang sudah ditentukan, meminta jadwal dokter di RS dan output yang dihasilkan berupa Informasi pelayanan rumah sakit melalui web [12]. Jenis hardware yang digunakan yaitu Handphone dengan SMS Autoreplay.

Mengembangkan dengan webbase dengan proses User mengunjungi web, melihat informasi dan melakukan pendaftaran dan output yang dihasilkan SMS untuk pelanggan atau nomor yang dikehendaki [15]. Perangkat yang digunakan modem GSM dengan model pengiriman SMS broadcast. Menurut penelitiannya bahwa Aplikasi ini menyediakan fungsi layanan pesan dan pencarian data yang terhubung ke server. Sistem akan mengirimkan permintaan pencarian data ataupun pengiriman pesan ke server untuk diproses. Apabila permintaan berupa pencarian data, maka sistem akan meneruskan ke server, dan apabila berupa pengiriman pesan, sistem akan meneruskan ke e-mail atau SMS Gateway.

Penelitian tentang antrian pasien pada sistem antrian yang dapat mendukung kelancaran pelayanan kepada masyarakat dan Implementasi aplikasi antrian berbasis SMS Gateway yang telah memberikan efisiensi waktu yaitu dapat mengatur waktu tunggu pasien dan keluarganya [3].

SMS Gateway diterapkan untuk Pelayanan registrasi pasien, Informasi jadwal dokter dan Penerimaan saran/kritik dari pasien atau masyarakat menggunakan berbasis web [12]. Berdasarkan ketiga hasil penelitian terdahulu didapatkan bahwa SMS gateway dapat diaplikasikan pada bidang kesehatan, menggunakan teknologi webserver gammu dan autoreply, namun yang membedakan dengan penelitian sekarang adalah: Database yang dirujuk diambil dari 
tabel pada sistem informasi di rumah sakit yang memiliki entitas yang berbeda. Proses pendistribusian informasi yang akan diberikan dengan cara auto reply dan broadcast. Pasien dalam mendapatkan informasi sesuai dengan format pesan yang dikirimkan ke server serta Rumah Sakit dapat menyebarkan informasi melalui SMS Broadcast.

\section{METODE PENGEMBANGAN SISTEM}

Sistem informasi ini dirancang menggunakan metode pengembangan System Development Life Cycle (SDLC). Kegiatan yang dilakukan pada tahap perencanaan sistem [9] yaitu:

a. Mendefinisikan Masalah

Masalah utama yang muncul dari sistem pendaftaran pasien rawat jalan yang telah berjalan yaitu informasi yang dihasilkan hanya bisa digunakan untuk lingkup internal saja.

b. Menentukan Tujuan Sistem

Memudahkan dalam mendapatkan informasi waktu kontrol ulang, antrian periksa serta kehadiran dan ketidakhadiran dokter di poliklinik secara real time.

c. Mengidentifikasi Kendala

Penambahan investasi hardware berupa pulsa sistem SMS gateway. Pembuatan Sistem dan Prosedur untuk menjalankan SMS Gateway. Pelatihan bagi karyawan yang terlibat dalam sistem tersebut. Sosialisasi Internal untuk dapat mengoperasikan sistem SMS gateway. Sosialisasi eksternal kepada masyarakat.

\subsection{Activity Diagram Operator}

Operator sebagai user sistem SMS gateway dengan kewenangan terbatas mempunyai tugas untuk mengelola jadwal dokter, mengelola grup, mengelola phonebook, mengirim SMS, mengelola inbox, mengelola outbox, dan mengecek pulsa. Gambar 4 menunjukkan activity diagram yang dilakukan oleh operator diawali dengan proses login.

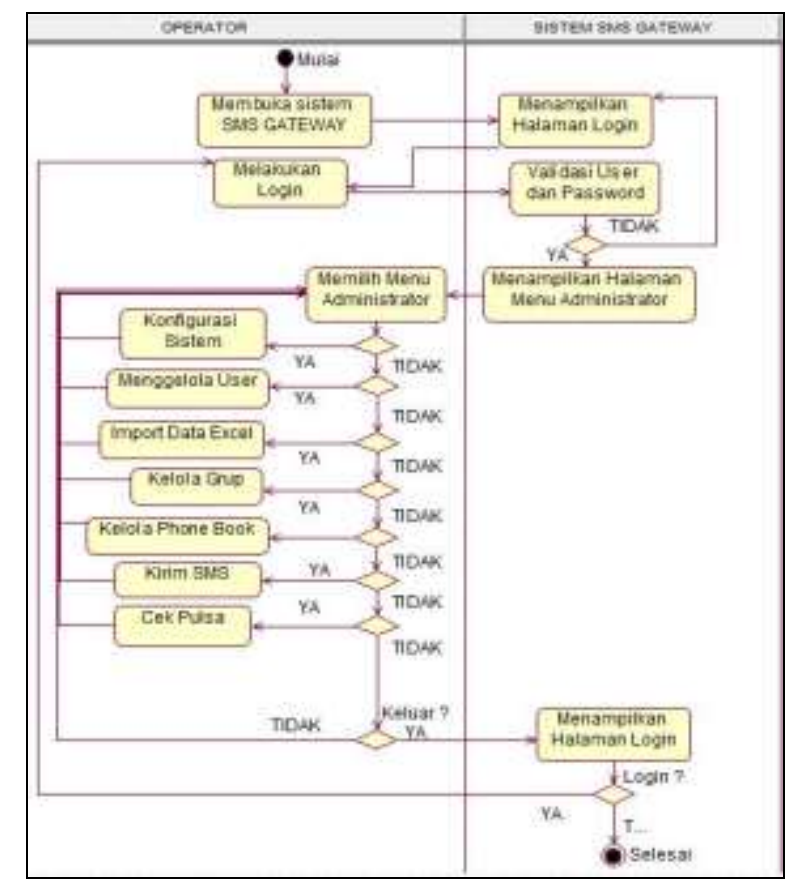

Gambar 4. Activity Diagram Operator SMS Gateway

\subsection{Pemodelan Data Sistem SMS GATEWAY}

a. Entity Relationship Diagram (ERD)

Entity Relationship Diagram (ERD) sistem pengolah SMS gateway menerangkan bahwa Entitas dokter berpasangan one to one. Dokter memiliki relasi many to many dengan entitas jadwal dan entitas regestrasi, Relasi many to many dengan entitas jadwal dan spesialis, 
menunjukan bahwa regestrasi memiliki banyak jadwal dan regestrasi memiliki banyak spesialis, demikian juga sebaliknya seperti yang di tunjukan pada Gambar 5.

b. Tabel Database

Gammu sebagai service yang menjalankan sistem SMS gateway mempunyai sembilan tabel yaitu: tabel daemons, tabel inbox, tabel outbox, tabel outbox_multipart, tabel pbk, tabel pbk_groups, tabel phones dan tabel sentitems.

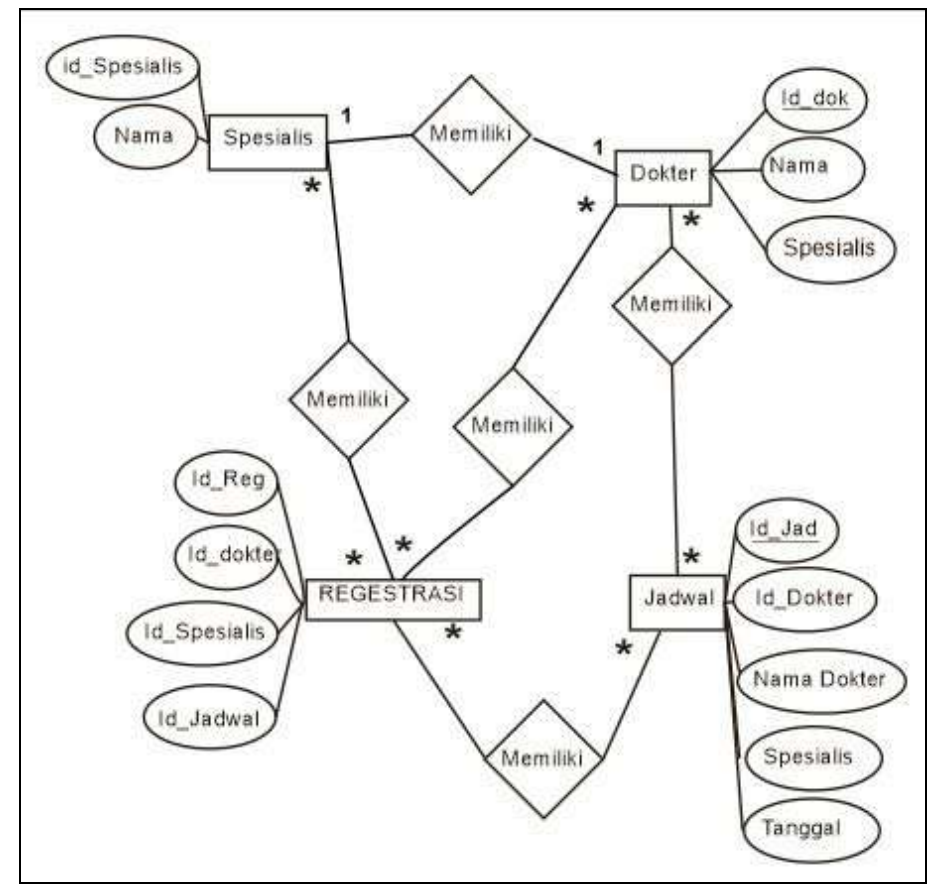

Gambar 5 ERD Sistem SMS Gateway

c. Relasi Database

Tabel pada sistem SMS gateway tidak semuanya saling berelasi karena sistem bertugas menyampaikan informasi yang telah diolah oleh sistem informasi rumah sakit seperti ditunjukan pada Gambar 6.

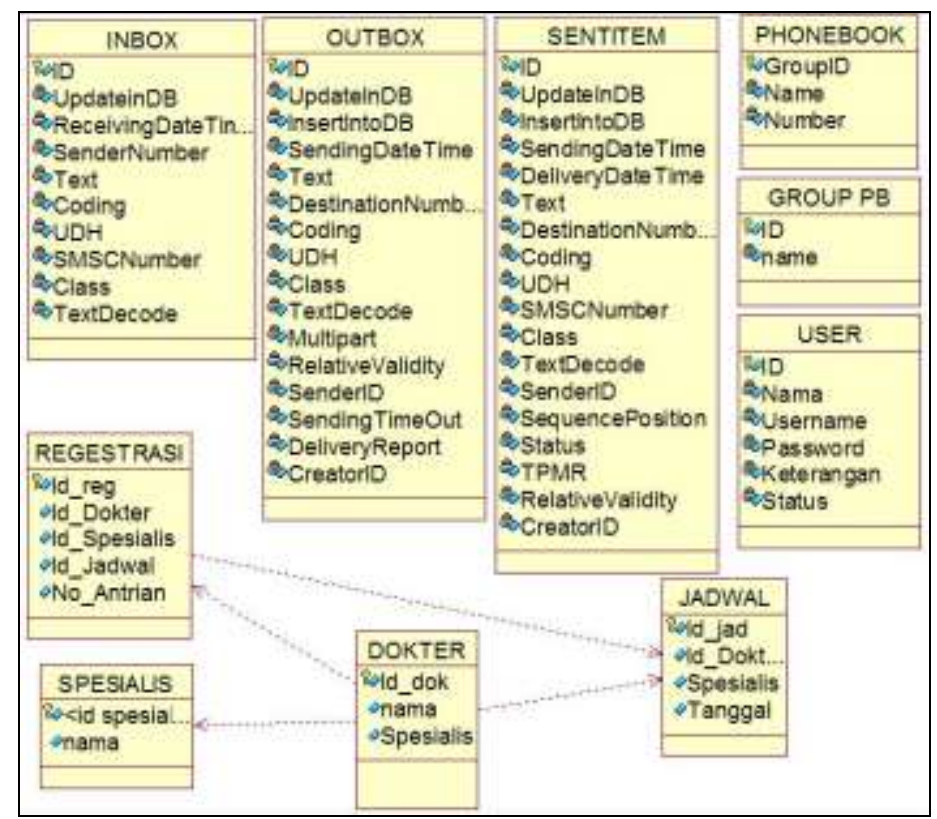

Gambar 6 Relasi Tabel dalam Sistem SMS Gateway 


\section{4. . HASIL DAN PEMBAHASAN}

\subsection{Instrumen Penelitian}

Perangkat penelitian digunakan untuk aplikasi yang terdiri dari perangkat lunak dan perangkat keras diantaranya:

1. Perangkat Keras yang Digunakan

Perangkat keras yang digunakan untuk menjalankan sistem aplikasi ini selama proses penelitian sebagai yaitu: Sisi Server: Notebook dengan spesifikasi, Processor: Intel Core i3, Memory: 2 GB DDR3, Harddisk: 320 GB, Monitor, Keyboard, Mouse.

Simcard GSM dengan layanan lokal, nomor handphone ini digunakan sebagai identifikasi pengirim SMS kepada pasien dan masyarakat. Sisi Client: Handphone: Nokia C3 atau tipe GSM lainnya, Simcard GSM atau CDMA yang beredar di Indonesia

2. Perangkat Lunak yang Digunakan

Dalam implementasi aplikasi ini yaitu:

Operating Sistem: Microsoft Windows 7 Profesional, Web Server $\quad$ : $\quad$ XAMPP 1.7.1, Gateway: Gammu Versi 1.27.1, Database : MySQL client version: 5.1.33, Web Browser : Firefox, Operator : Indosat IM3

\subsection{Hasil Implementasi Sistem}

Aplikasi berbasis SMS gateway yang dikembangkan bernama SMS RAJA (SMS Rawat Jalan) dalam proses pengujian mampu menyampaikan informasi 2 arah kepada pasien berupa Informasi Jadwal dokter, No Antrian, dan Pendaftaran Pasien dari petugas RS dengan level administrator yang bertanggung jawab untuk merawat sistem dan operator yang bertugas untuk menjalankan sistem.

1. Halaman Login Administrator atau operator, seperti ditunjukan pada Gambar 8.

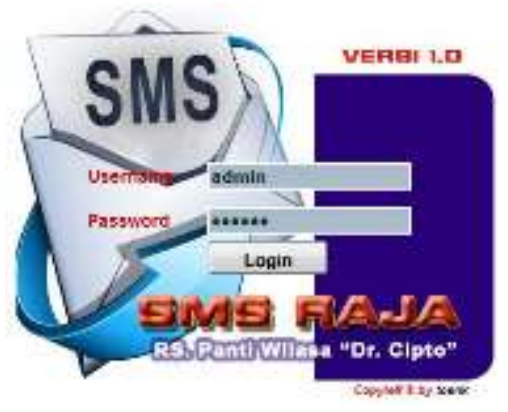

Gambar 8. Halaman Login

2. Halaman Utama berisi informasi jumlah SMS masuk, keluar, phonebook, seperti ditunjukan pada Gambar 9.

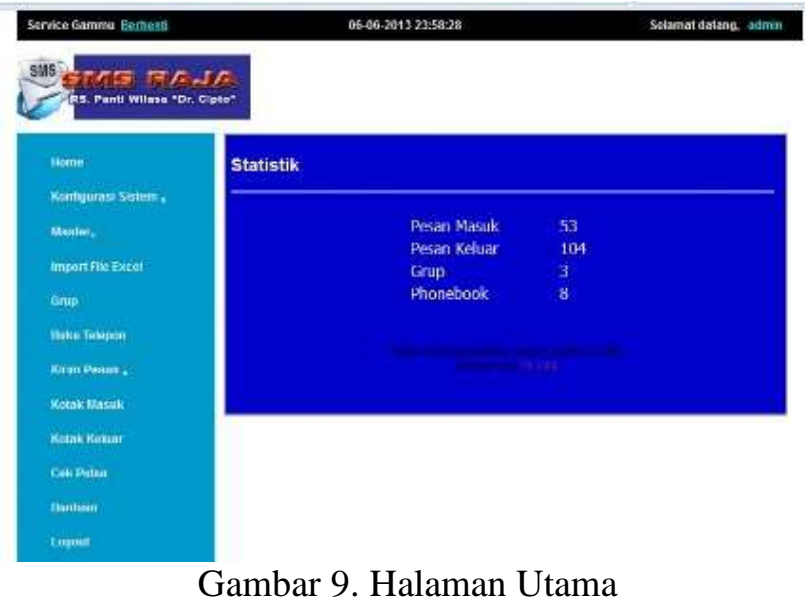


a. Menu Master User untuk mengelola user tambah, edit, dan hapus, seperti ditunjukan pada Gambar 10.

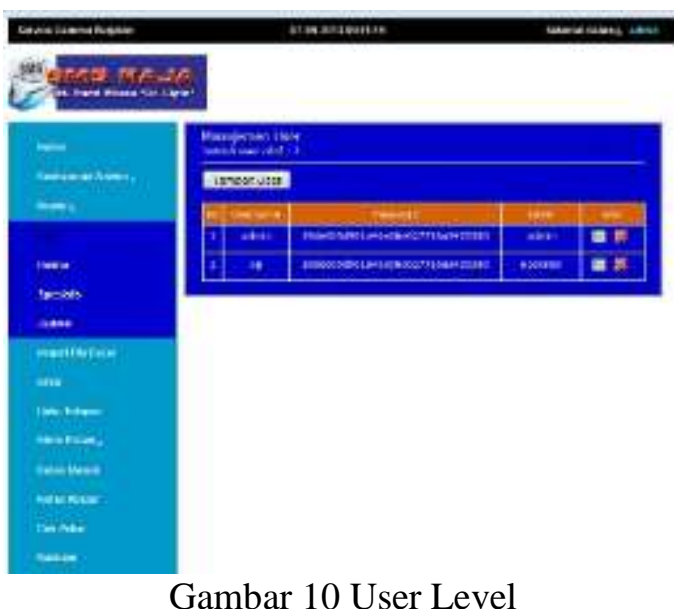

b. Menu Dokter mengelola dokter yang ada di rumah sakit seperti tambah, edit, dan hapus, seperti ditunjukan pada Gambar 11.

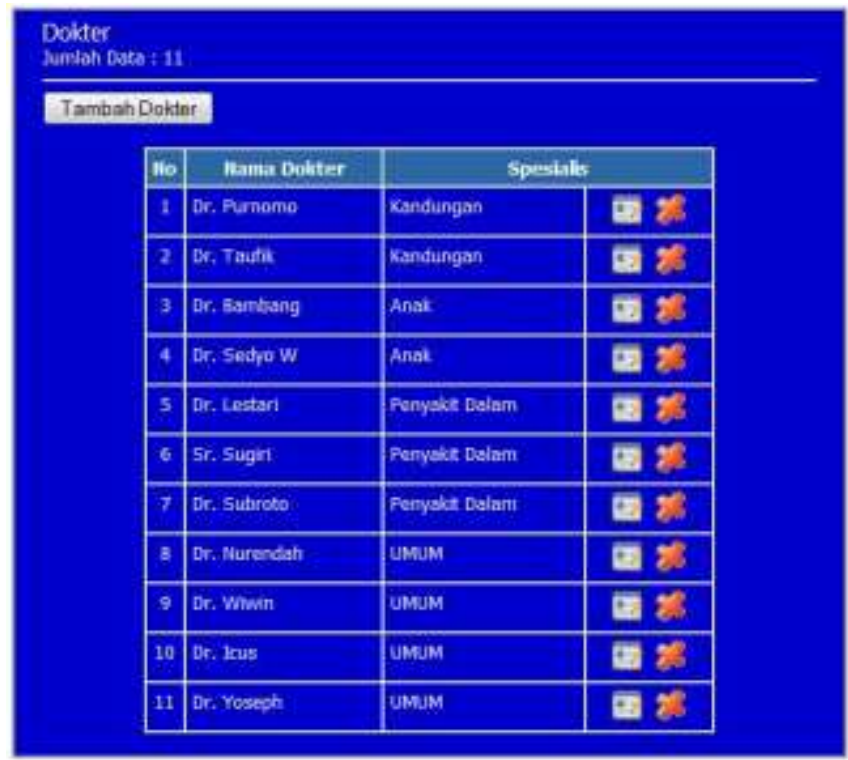

Gambar 11. Menu Dokter

c. Menu Spesialisasi untuk mengelola dokter spesialisasi yang ada di rumah sakit seperti tambah, edit, dan hapus, seperti ditunjukan pada Gambar 12.

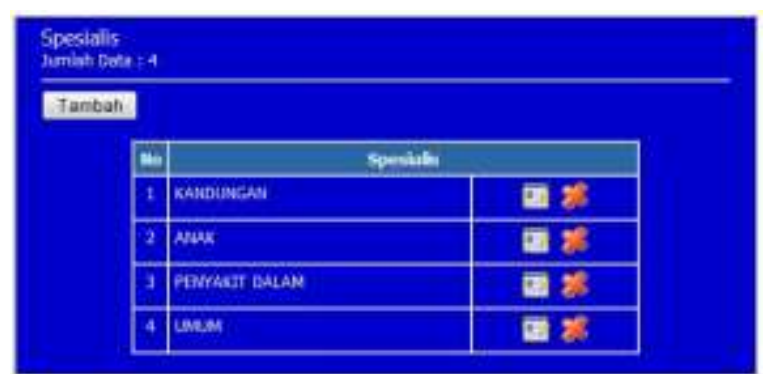

Gambar 12. Menu Spesialis 
d. Menu Jadwal mengelola jadwal Praktek dokter yang ada di rumah sakit seperti tambah, edit, dan hapus, seperti ditunjukan pada Gambar 13.

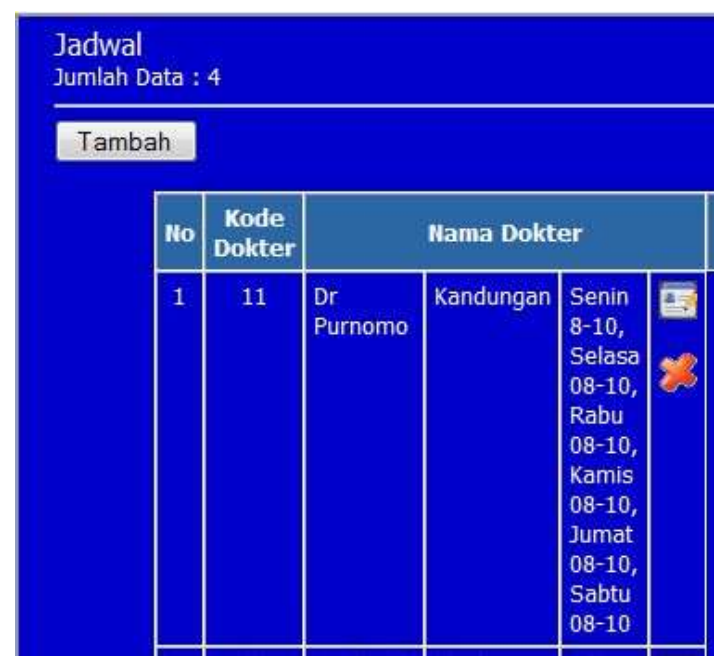

Gambar 13. Menu Jadwal

3. Import File untuk melakukan pengambilan data dari file format excel (.xls) sehingga pengguna dapat menambahkan phonebook dalam jumlah banyak, seperti ditunjukan pada Gambar 14

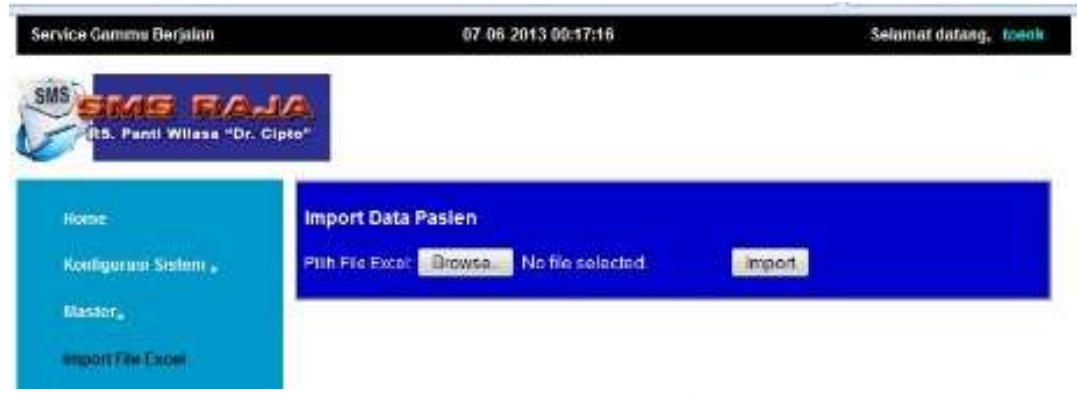

Gambar 14. Tambah Data melalui Import Excel

4. Grup Menu berfungsi untuk mengelompokkan pasien dan dokter menurut spesialisasinya, seperti ditunjukan pada Gambar 15.

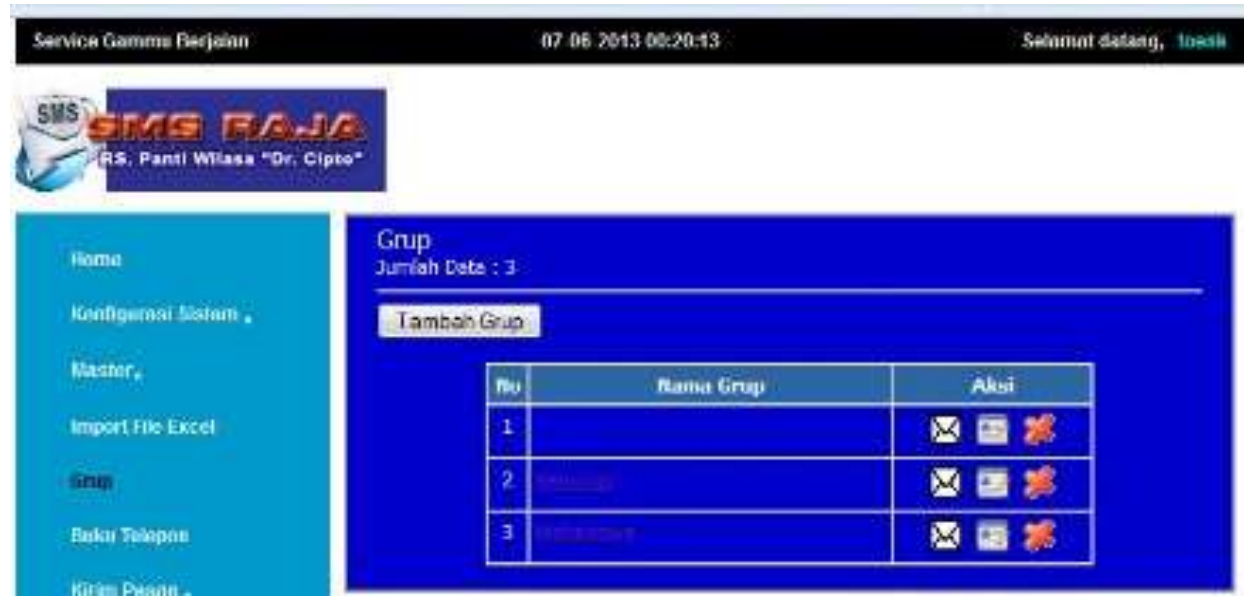

Gambar 15. Menu Grup 
5. Phonebook pada sistem, seperti ditunjukan pada Gambar 16.

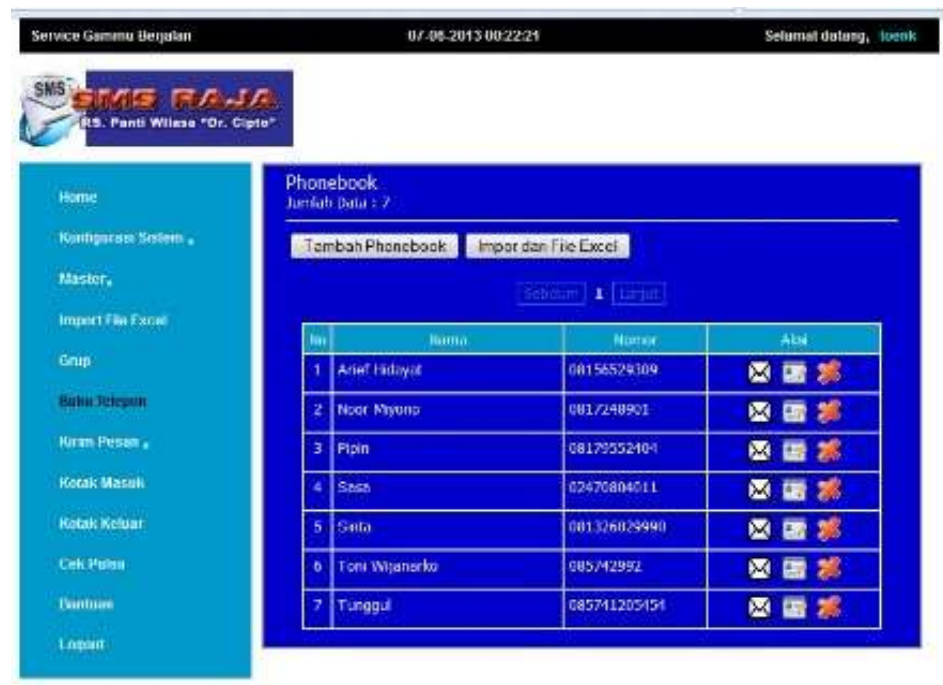

Gambar 16. Menu Phonebook

Link menu Kirim SMS pada kolom Aksi, seperti ditunjukan pada Gambar 17.

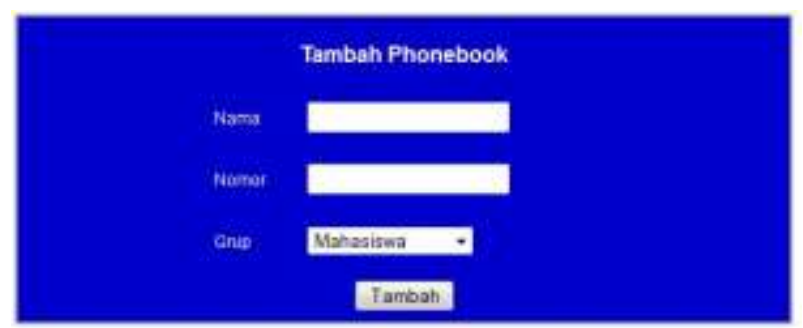

Gambar 17. Tambah Phonebook

6. Kirim SMS digunakan untuk mengirim SMS, seperti ditunjukan pada Gambar 18.

7. Inbox berisi informasi waktu SMS masuk, nomor pengirim, dan aksi, seperti ditunjukan pada Gambar 19.

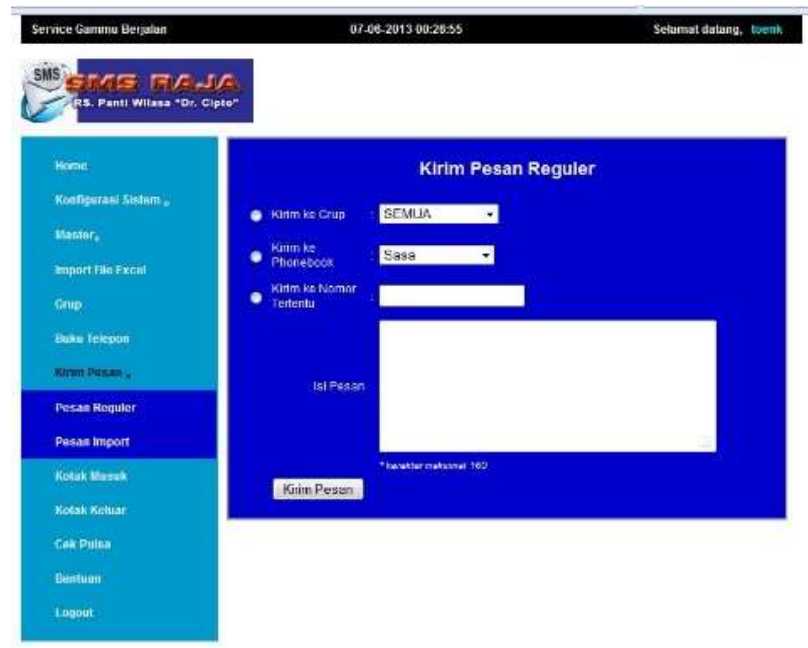

Gambar 18 Kirim Pesan Reguler 


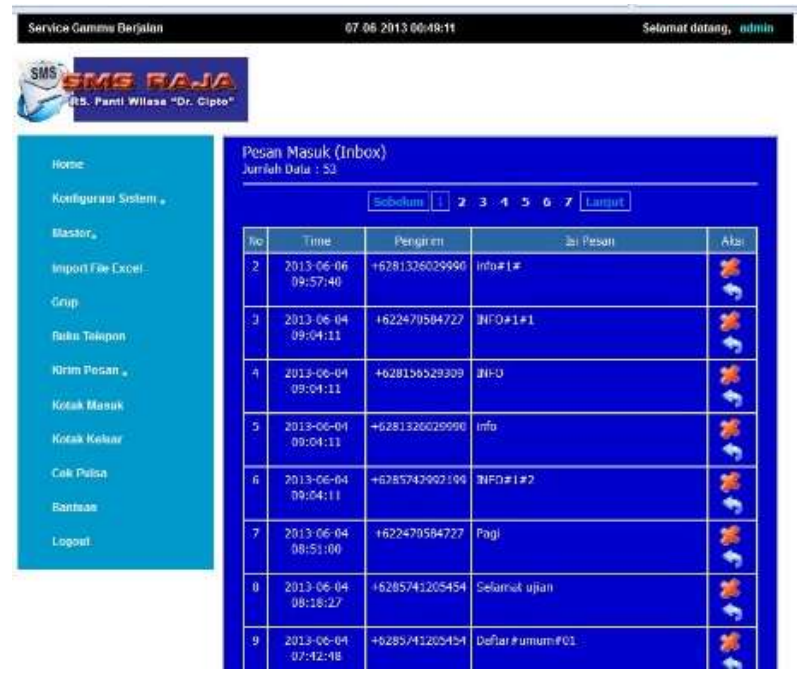

Gambar 19 Menu Inbox

8. Outbox berisi informasi SMS yang keluar dari sistem, waktu pengiriman SMS, nomor tujuan, isi pesan, status SMS (terkirim atau gagal), link hapus, seperti ditunjukan pada Gambar 20.

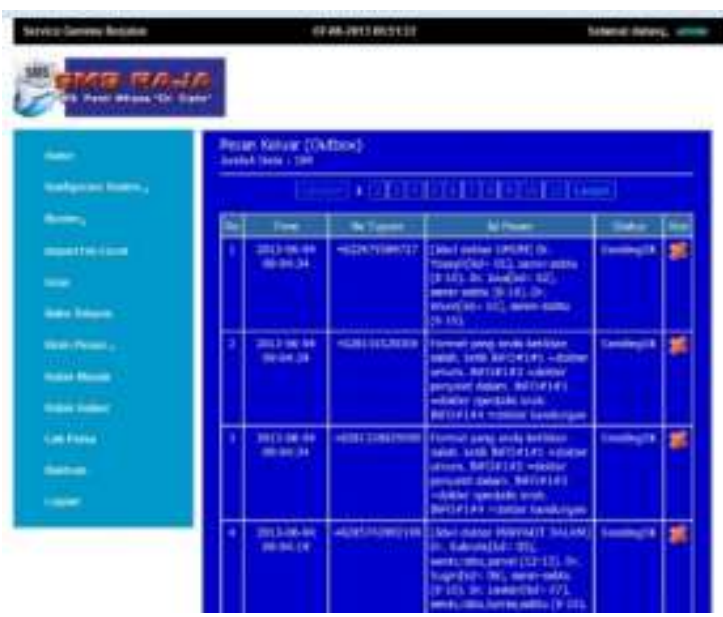

Gambar 20 Menu Outbox

9. Cek Pulsa berfungsi untuk melihat sisa pulsa yang bisa digunakan dalam sistem, seperti ditunjukan pada Gambar 21.

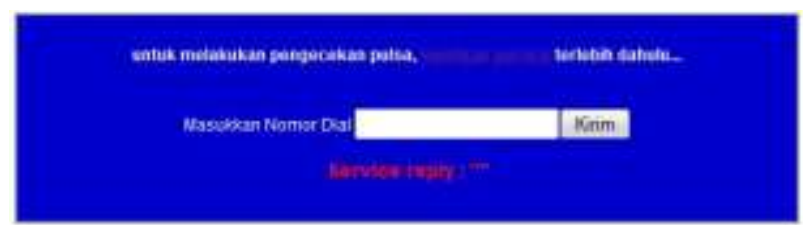

Gambar 21. Cek Pulsa

\subsection{SMS Auto Replay}

Pasien lama atau pasien kontrol dapat menggunakan fasilitas autoreply untuk mendapatkan informasi tentang Jadwal Praktek Dokter atau melakukan pendaftaran lewat SMS, seperti ditunjukan pada Gambar 22 dan 23. 


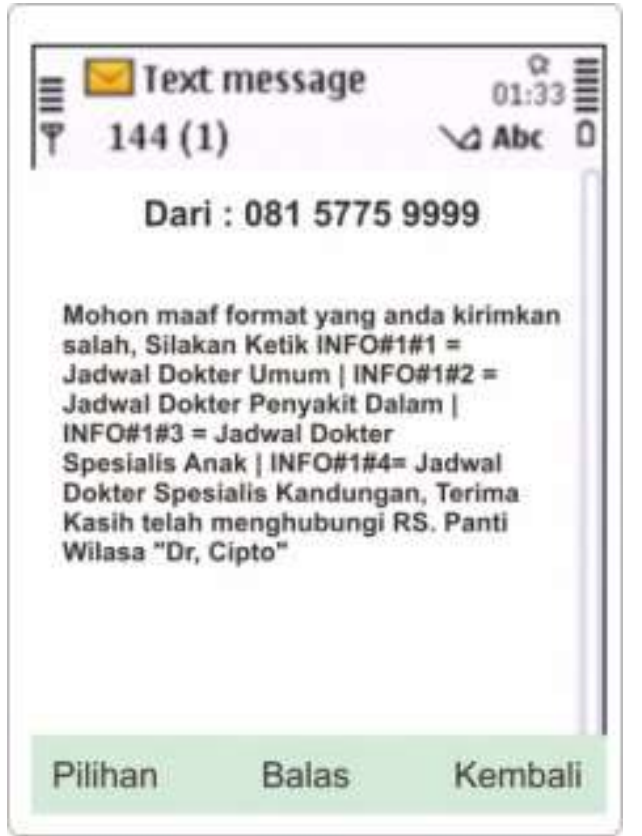

Gambar 22 SMS Balasan Autoreply Format Salah

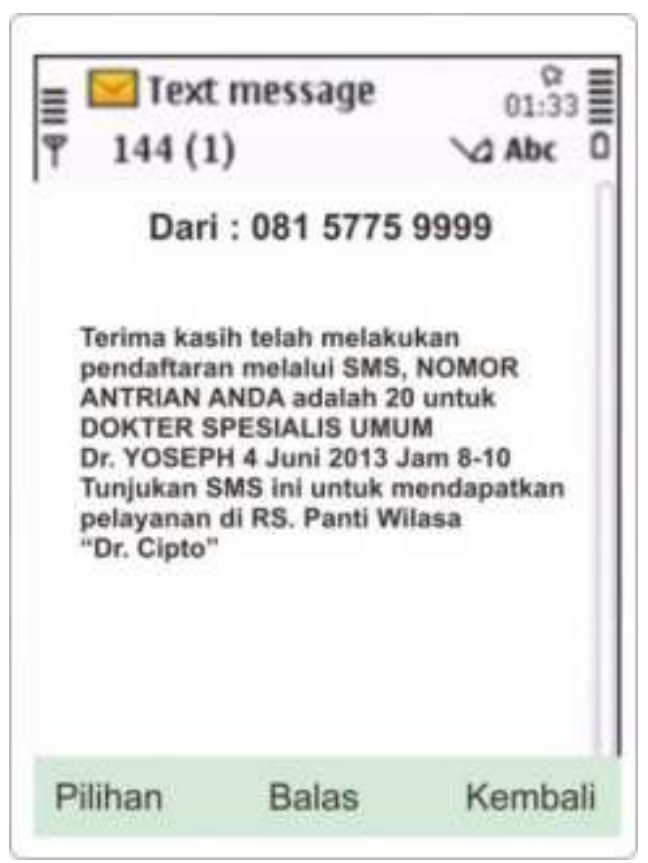

Gambar 23 SMS Balasan Autoreply Format Benar

\subsection{Pembahasan}

Berdasarkan simulasi sistem informasi pendaftaran rawat jalan berbasis SMS gateway selanjutnya dilakukan pembahasan terhadap sistem berjalan. Pembahasan dilakukan dengan melihat hubungan sistem dengan kebutuhan pasien terhadap informasi yang ingin didapatkan. Berdasarkan hasil penilaian pada simulasi sistem, pembahasan meliputi:

a. Kemudahan penyampaian informasi Seputar RS. Panti Wilasa "Dr. Cipto".

Dengan sistem SMS RAJA pada menu kirim SMS, penyampaian informasi menjadi lebih mudah dilakukan pihak rumah sakit kepada pasien atau masyarakat pengguna layanan kesehatan. Informasi yang disampaikan biasanya bersifat umum seperti kegiatan donor darah rutin, kegiatan 
hospital tour, kegiatan senam hamil, kegiatan internal rumah sakit bagi karyawan dan promosi yang lain.

b. Kemudahan penyampaian informasi Kontrol Ulang Pasien RS. Panti Wilasa "Dr. Cipto".

Pengiriman informasi kontrol ulang kepada pasien atau keluarganya dengan harapan dapat mengingatkan pasien untuk kontrol kembali ke dokter atau ke rumah sakit sehingga proses penyembuhan penyakit secara holistik dapat dicapai oleh pasien. Data ini diperoleh dari hasil ekspor database Sistem Informasi Rumah Sakit (SIRS) RS. Panti Wilasa "Dr. Cipto" berupa file excel (*.xls) yang sudah ditentukan kolomnya seperti ditunjukan pada Gambar 25 untuk dipakai rumah sakit sebagai materi pengiriman SMS Kontrol Ulang disesuaikan dengan keterangannya yaitu KONTROL, jika data pasien yang dihasilkan memuat hasil dikolom keterangan adalah kontrol maka sistem SMS RAJA akan melakukan pengiriman SMS ke nomor tujuan.

c. Kemudahaan mendapatkan Informasi Jadwal Dokter dan Pendaftaran Periksa.

Pasien atau keluarganya yang ingin mengetahui jadwal dokter yang praktek di RS. Panti Wilasa "Dr. Cipto" mendapatkan kemudahan dengan mengirimkan SMS berformat tertentu. Pasien bisa mengirim SMS ke pusat layanan SMS RAJA dengan mengetik INFO\#1\#1\#1 untuk mendapatkan jawaban otomatis jadwal dokter yang diinginkan, demikian juga halnya saat pasien akan melakukan pendaftaran periksa, pasien dapat menggunakan fasilitas pengiriman SMS dengan format DAFTAR\#1\#1\#1 yang secara otomatis pasien mendapatkan nomor antrian dengan informasi nama dokter dan hari serta jam prakteknya.

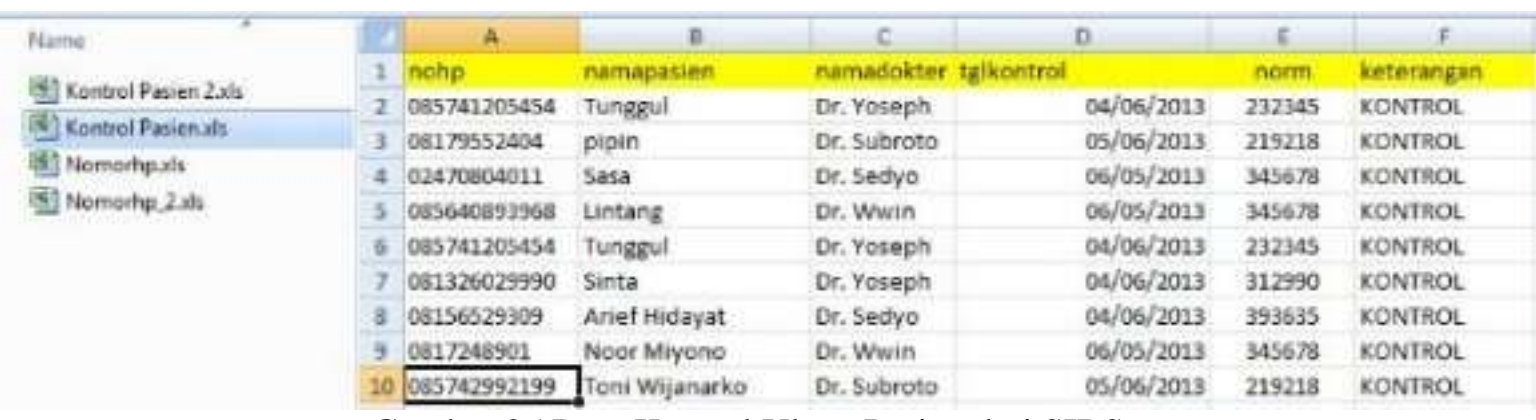

Gambar 25 Data Kontrol Ulang Pasien dari SIRS

Informasi melalui sistem SMS gateway meminimalisir terjadinya informasi yang tidak sampai ke nomor tujuan. Sistem informasi berbasis SMS gateway tentunya juga memiliki permasalahan terkait jaringan yang dipakai oleh penerima, tetapi ketika ada informasi yang gagal disampaikan kepada pasien dan masyarakat sistem akan memberi pesan peringatan sehingga dapat dilakukan pengiriman ulang.

d. Kecepatan penyampaian Informasi

Sistem Informasi berbasis SMS gateway mampu menyampaikan informasi ke banyak nomor sekaligus dengan menerapkan sistim antrian di mana satu informasi dapat dikirim dalam waktu 1-2 menit tergantung jaringan nomor seluler yang digunakan.

\section{KESIMPULAN DAN SARAN}

\subsection{Kesimpulan}

Berdasarkan hasil pembahasan Perancangan Sistem Pendaftaran Pasien Rawat Jalan berbasis SMS gateway, maka kesimpulan yang di dapat adalah sebagai berikut:

Data Pasien dengan status kontrol ulang dari rumah sakit yang di import menjadi file excel (.xls) dapat digunakan untuk proses lanjutan sebagai pemberitahuan dan pengingat kepada pasien untuk melakukan kontrol kesehatannya.

Fitur Auto Reply yang disertakan dalam sistem ini mengurangi beban pekerjaan bagian terkait karena sudah bisa dikerjakan oleh sistem SMS gateway. 


\subsection{Saran}

Saran dalam penelitian ini yaitu:

Untuk pengiriman SMS massal atau bervolume besar dibutuhkan dukungan perangkat modem yang lebih besar. Sistem SMS gateway ini belum mencetak laporan hasil dari proses pendaftaran pasien yang menghasilkan nomor antrian pasien. Sistem SMS gateway ini dapat dikembangkan tiga arah antara pasien, dokter dan rumah sakit secara kesinambungan.

\section{References}

[1] Gunawan, W. 2010. Kebut Sehari jadi Master PHP. Yogyakarta: Genius Publisher.

[2] Hastuti, F.S. 2008. Pemanfaatan teknologi WAP pada sistem Pemesanan Tiket KA. Jakarta

[3] Iskandar, Fajar Fiji. 2012. "Penerapan SMS Gateway Pada Sistem Antrian Di Puskesmas Seppong" Makassar: Jurnal STMIK Kharisma.

[4] Jogiyanto, HM. 2007. Analisis dan Desain Sistem Informasi: Pendekatan Terstruktur Teori dan Praktik Aplikasi Bisnis. Yogyakarta: Andi.

[5] Kadir, A. 2009. Dasar Perancangan \& Implementasi. Yogyakarta: C.V Andi Offset.

[6] Keputusan Menteri Kesehatan RI No: 983/Menkes/SK/XI/1992 tentang tugas rumah sakit.

[7] Kristanto, Andri. 2008. Perancangan Sistem Informasi dan Aplikasinya. Yogyakarta : Gava Media

[8] Mulyanto, Agus. 2008. Sistem Informasi Konsep \& Aplikasi. Yogyakarta : Pustaka Ilmu

[9] Munawar. 2005. Pemodelan Visual dengan UML. Yogyakarta: Graha Ilmu.

[10] PERMENKES No: 269/MENKES/PER/III/2008 tentang Rekam Medis

[11] Prosedur Tetap RS. Panti Wilasa "Dr. Cipto, 2010 tentang Prosedur Penerimaan Pasien Rawat Jalan

[12] Santika, I Made Wira Adi. 2010. "Layanan Informasi Untuk Pasien Rumah Sakit Menggunakan SMS" Yogyakarta: Jurnal Vol 13 Universitas Sanata Dharma.

[13] Saputra, Agus. 2011. Membangun Aplikasi SMS dengan PHP dan MySQL. Jakarta : PT. Elex Media Komputindo

[14] Supriyanto, Aji. 2007. Pengantar Teknologi Informasi. Jakarta : Salemba Infotex

[15] Thoyib, 2010. "Pelayanan Pelanggan Berbasis SMS Gateway" Jurnal Universitas Mercu Buana. Jurnal UMB/Aplikasi SMS Gateway/2010

[16] Undang-Undang (UU) Republik Indonesia No.44 Tahun 2009 tentang Rumah Sakit. 